\begin{tabular}{c} 
Volume and Issues Obtainable at Center for Sustainability Research and Consultancy \\
Journal of Business and Social Review in Emerging Economies \\
ISSN: 2519-089X (E): 2519-0326 \\
Volume 6: No. 1, March 2020 \\
CSRᄃ \\
Journal homepage: www.publishing.globalcsrc.org/jbsee \\
\hline
\end{tabular}

\title{
How Does Stakeholders Pressure Affect Organization Performance and Employee Wellbeing? Study of Multiple Mediating Roles
}

\author{
${ }^{1}$ Khawaja Khalid Mehmood, ${ }^{2}$ Rabia Rasheed, ${ }^{3}$ Javeria Jaan \\ ${ }^{1}$ Assistant Professor, Institute of Management Sciences, Bahauddin Zakariya University, Multan, \\ Pakistan. khawjakhalid@bzu.edu.pk \\ ${ }^{2}$ Management Science, Iqra University, Karachi, Pakistan. rabia@globalcsrc.org \\ ${ }^{3}$ Institute of Management Sciences, Bahauddin Zakariya University, Multan, Pakistan. \\ javeria.jaaaan@yahoo.com
}

\begin{tabular}{l} 
ARTICLE DETAILS \\
\hline History \\
Revised format: February 2020 \\
Available Online: March 2020
\end{tabular}

\section{Keywords}

Organization Performance,

Employee wellbeing,

Corporate Social

Responsibility, Stakeholder

Pressure.

\section{JEL Classification:}

D23, M14, O15

\begin{abstract}
Purpose: Employee satisfaction and high performance is every organization's goal. When seen through the lens of stakeholder theory, these goals could be achieved by CSR practices through certain ways. Stakeholder theory affords an initial point to assimilate stakeholder pressure and corporate social responsibility practices. This research studies the effect of pressure from stakeholders over organization performance and wellbeing of employees by including the mediating effect of CSR oriented culture, CSR practices, organizational citizenship behavior, organizational commitment, and organizational trust in Pakistan's banking sector.
\end{abstract}

Design/Methodology/Approach: The study employs quantitative and cross sectional research design. A sample of 180 banks was studied through employing SmartPLS3.0 software using mediation analyses.

Findings: The findings reveal that CSR oriented culture mediates between stakeholder pressure and CSR practices; CSR practices affect organization performance through organization citizenship behavior. Further, trust is a partial mediator among CSR practices and wellbeing of employees. Serial mediators play their role between stakeholder pressure and organization performance, and also play a role between stakeholder pressure and employee wellbeing. Implications/Originality/Value: The findings suggest Pakistani banks to acknowledge pressure from all stakeholders, and concentrate on CSR practices for their bank performance and staff wellbeing.

\section{OPEN ACCESS}

(C) 2020 The authors, under a Creative Commons AttributionNonCommercial 4.0

Corresponding author's email address: javeria.jaaaan@ yahoo.com

Recommended citation: Mehmood, K. K., Rasheed.R. \& Jaan, J., (2020). How Does Stakeholders Pressure Affect Organization Performance and Employee Wellbeing? Study of Multiple Mediating Roles. Journal of Business and Social Review in Emerging Economies, 6(1), 55-68

DOI: $10.26710 /$ jbsee.v6i1.1026

\section{Introduction}

CSR has gained importance due to its academic and practical implications and it has become a frequently studied variable in recent researches. Competent organizations all over the world realize its implications 
and include it in their strategic management. For instance, almost 53\% of Thai companies display CSR contents on their websites (Phunpon \& Pumtong, 2012). The recent scandals of Enron and WorldCom have reported importance of ethical issues and CSR reporting. Amongst others, banks are also under pressure to address CSR in their operations (Lindblom, 1994).

But, organization performance and CSR link is still a black box as different findings like positive, negative and even no link have been reported by past studies (Agle, Mitchell, \& Sonnenfeld, 1999; Margolis \& Walsh, 2001; Jin \& Drozdenko, 2010). The differences among the findings could be attributed to possible intervening variables like employee trust, attitude, and behavior as revealed by certain past scholars. Societies these days have greater awareness and demand environmental based activities and especially welfare based activities for employees. Scholars argue that employee wellbeing is related to CSR or is in fact result of corporate social responsibility practices CSRP (Bauman \& Skitka, 2012; Maignan \& Ferrell, 2001). According to Bauman and Skitka (2012), various employee needs could be fulfilled through CSR activities. Further, researchers argue that trust also provides a mechanism between CSRP and employee attitude (Sarfraz, Qun, Abdullah, \& Alvi, 2018).

Social identity theory and social exchange theory explain the relation between an organization and its employees' perception about its CSR activities. Cropanzano and Rupp (2008) argue that justice related aspect in social exchange theory refers that a level of trust is developed through exchange relationship between employees and their organization through internal CSR impact (Cropanzano \& Mitchell, 2005). A number of previous researchers (Rupp, Shao, Thornton, \& Skarlicki, 2013; El Akremi, Gond, Swaen, de Roeck, \& Igalens, 2015) describe that employee behavior as well as attitude have an impact on achievement of firm objectives and goals through employees' CSR perception. Social identity theory implies that workers associate themselves to reputable organizations proudly (Maignan \& Ferrell, 2001). They develop sense of motivation through their firm's external CSR activities (Mael \& Ashforth, 1992). Gavin and Maynard (1975) suggest that employees feel satisfied with their jobs when their organization adequately fulfills its social obligations.

On the other hand, firm stakeholders exert pressure on it for CSR activities (Kowalczyk, 2019). Scholars have argued that a firm's CSR oriented culture might be an intervening variable between stakeholder pressure and CSRP (Kalyar, Rafi, \& Kalyar, 2013; Kowalczyk, 2019). In fact, RBV describes culture as a resource that if it does not support firm CSR activities then the firm might not practice CSR activities in spite of high stakeholder pressure (Darnall, 2006). Hence, the effect of pressures from stakeholders concerning CSRP on organization performance and wellbeing of employees is gaining interest among scholars. But, there have been extremely limited studies that examine these possible linkages as well as the role of possible mediators like organizational trust, organizational citizenship behavior, and organizational commitment. This study fills this gap by analyzing this framework with reference to Pakistan's banks.

In any country, banking sector is facilitator of organizational and individual level transactions and banking industry, therefore, holds supreme importance. Pakistan's banking sector is no exception. In 1990, privatization occurred in Pakistan. During this period, banking sector increased its GDP contribution to $52 \%$ from $24 \%$ and attracted investors (Rehman, Zhang, Ali, \& Qadeer, 2015). The economic surveys of Pakistan 1 show that finance and insurance sector contribution increased up to $6.1 \%$ in the year 2014-2015 form 5.2\% in the year 2013-2014. This study selected banks for analyses because of banks' significant contribution to Pakistan's economy and due to their organized nature of structure that allowed smooth collection of data. 


\section{Theoretical Basis and Hypotheses Formulation}

\subsection{Stakeholders Pressure, CSR Oriented Culture, and CSRP}

Freeman (1984) explained stakeholder theory describing the category and importance of various stakeholders and their demands. Scholars have asserted that firm's internal and external stakeholders exert pressure on it for doing CSRP (Wang, Li, \& Qi, 2020). The pressure is exerted on firms not just for them to obey basic law but also to consider welfare of the society (Kowalczyk, 2019; Sarkis, Gonzalez-Torre, \& Adenso-Diaz, 2010). Stakeholders demand socially responsible behavior for all; including internal CSRP for employees and external CSRP for customers (Aguinis \& Glavas, 2012). To illustrate, findings of research by Yu and Choi (2016) on Chinese firms with sample of 168 showed positive relation between stakeholder pressure and firms' CSRP. Another study for MNE's in South Korea displayed significant relationship between the two (Park, Chidlow, \& Choi, 2014).

Importantly, according to resource based view, organization culture is a resource that could affect firm's adoption of CSRP (Takahashi \& Nakamura, 2005). CSR oriented culture is a set of beliefs, values, and norms about CSR. This culture is created through harmony between all the organization members (Linnenluecke \& Griffiths, 2010). Scholars argue that for proper adoption of CSR activities, firms formulate a culture supportive to CSR activities (Kalyar et al., 2013; Kowalczyk, 2019; Linnenluecke \& Griffiths, 2010) and pressure from stakeholders could deliver imputes for it (Stone, Joseph, \& Blodgett, 2004). Based on the discussion and in line with previous scholars (such as Kim \& Lee, 2012) following hypothesis is formulated:

\section{H1: CSR-oriented culture mediates between stakeholder pressure and CSRP.}

\subsection{CSRP, Commitment, and Performance}

Firm's CSRP lead toward higher performance is an argument of stakeholder theory (Freeman, 1984). To support, a positive relationship between CSR practices and organizational performance was found by Reverte, Gómez-Melero, and Cegarra-Navarro (2016) in Spain. Further, a meta-analysis study by Boaventura et al. (2012) in Brazil also confirmed positive relationship between the two. As noted earlier, theoretical arguments imply that workers associate themselves to reputable organizations proudly and remain committed and satisfied (Maignan \& Ferrell, 2001). Boadi, He, Bosompem, Opata, and Boadi (2019) recently reported significant effect of employees' perception of their CSR on their performance and corporate identification.

Organizational commitment was defined by O'Reilly (1989) as an individual's psychological attachment with the organization through which he believes in organization's values and develops sense of job engagement and loyalty. An empirical study on 269 business professionals in Turkey showed significant influence of CSRP over commitment from employees (Turker, 2009). This was too confirmed by certain other scholars (Ali, Rehman, Ali, Yousaf, \& Zia, 2010; Peterson, 2004). Scholars also suggested that firm performance and output could be increased by highly committed staff (Chun, Shin, Choi, \& Kim, 2013; Supriyanto, Ekowati, \& Maghfuroh, 2020). Thus, based on the discussion made, following could be hypothesized:

\section{H2: Organizational commitment is mediating variable amongst CSRP and organization performance.}

\subsection{CSRP, Organization Citizenship Behavior, and Performance}

Salavati, Ahmadi, Sheikhesmaeili, and Mirzai (2011) described Organization Citizenship Behavior as an unforced extra work behavior that promotes performance and efficiency in an organization. The link between CSR practices and OCB is explained by social exchange theory. OCB is an outcome of interchange process as proposed by OCB theorists (Organ, 1988). Significant effect of CSR practices on OCB was discovered in the research by Hansen, Dunford, Boss, Boss, and Angermeier et al. (2011) in US context. Similarly, Lin et al. (2010) reported positive effect of CSRP on OCB as well. Similarly studies have suggested positive impact of OCB on organization performance (Nisar, Marwa, Ahmad, \& Ahmad, 
2014; Podsakoff, Whiting, Podsakoff, \& Blume, 2009) Hence, following hypothesis is formulated:

H3: Organizational citizenship behavior mediates between CSRP and performance.

\subsection{CSRP, Organizational Trust, and Performance}

OB theorists have also proposed that CSR activities impact employee attitude and behavior as these activities effectively build trust among employees (Cropanzano, Byrne, Bobocel, \& Rupp, 2001). Others (Rupp, Ganapathi, Aguilera, \& Williams, 2006) suggest that an employer's CSRP help in building employee trust. Similarly, others support the argument and claim that organizational trust is, in fact, an immediate outcome of organization's CSRP (Dirks \& Ferrin, 2001; Pivato, Misani, \& Tencati, 2008). Similarly, organizational trust impacts performance positively (Kramer, 1999; Wong, Wong, \& Ngo, 2002). Therefore, it could be hypothesized that:

\section{H4: Organizational trust mediates between CSRP and performance.}

\subsection{CSRP, Organizational Trust, and Employee Wellbeing}

It has been argued before that organizations which address CSR proudly identified by employees. Hence, there is a notable relationship between organization fulfillment of its social obligation and employees' satisfaction with their jobs. (Bauman \& Skitka, 2012; Pandey, 2020). Du, Bhattacharya, and Sen (2015), in their study for multiple industries, made different employees segments (enthusiasts, indifferents, and idealists) and studied impact of CSR activities. Results showed contentment of ideological and other job related needs through enhancement of job satisfaction and reduction in turnover intentions. This pointed towards improved employee wellbeing through higher job satisfaction.

Moreover, studies of Lee, Son, and Lee (2011) and Dirks and Ferrin (2001) showed positive influence of CSRP on trust. Moreover, other studies (Lee, Song, Lee, Lee, \& Bernhard, 2013; Lee, Kim, Lee, \& Li, 2012) found that trusted employees remained satisfied with their job leading to their high wellbeing. The discussion leads to following hypothesis:

H5: Organizational trust plays role of mediator between CSRP and wellbeing of employees.

\subsection{Role of serial mediators between Stakeholder Pressure and Performance}

Stakeholder theory (Freeman, 1984) elaborates that numerous stakeholders influence firm performance through their power. Firms prioritize stakeholders according to their needs. Firms, at first, satisfy shareholders explicit needs and then satisfy other stakeholders' implicit needs (Donaldson \& Preston, 1995). Organization's CSR activities are influenced by shareholders, customers, employees, society/NGOs and government which are most influential ones (Sarkis et al., 2010), and these CSR activities ultimately influence its performance. In response to stakeholders' pressure, firms develop some environmentally responsible strategies. In doing so, firms face some constraints like non-supporting organizational culture (Sarkis et al., 2010). As argued earlier, culture influences CSR activities and is likely a mediator among stakeholder pressure and CSRP (Kalyar et al., 2013). Similarly it has been argued and hypothesized earlier that association among CSRP and performance might be mediated by organization commitment, OCB, and organizational trust. Hence, hypotheses for serial mediation are developed as:

H6a: CSR oriented culture, CSRP and commitment act as serial mediators amongst stakeholder pressure and performance.

H6b: CSR oriented culture, CSRP and OCB act as serial mediators amongst stakeholder pressure and performance.

H6c: CSR oriented culture, CSRP and trust act as serial mediators amongst stakeholder pressure and performance. 


\subsection{Role of serial mediators between Stakeholder Pressure and Employee Wellbeing}

Employees are stakeholders, and shareholders suffer from their absence and sickness. Hence, it is important to ensure employee presence, satisfaction, and wellbeing. In order to keep employees active and healthy at work place, employers at minimum need to obey government rules and labor laws. Over and above, they need to adopt CSR activities. As argued earlier, employees consider such organizations more valuable and remain committed and satisfied with their jobs. On adoption of CSR practices, employees' safety, psychological, belongingness, and self-esteem needs are fulfilled, and sense of satisfaction is achieved (Bauman \& Skitka, 2012; Boadi et al., 2019). Further, as argued before, employees remain happy with their jobs when they have trust in their organizations and that results in their wellbeing (Lee et al., 2013). Hence, it leads to hypothesis H7. The research framework constructed for this study is provided in Figure 1.

H7: CSR oriented culture, CSRP and trust are serial mediators amongst stakeholder pressure and wellbeing of employees.

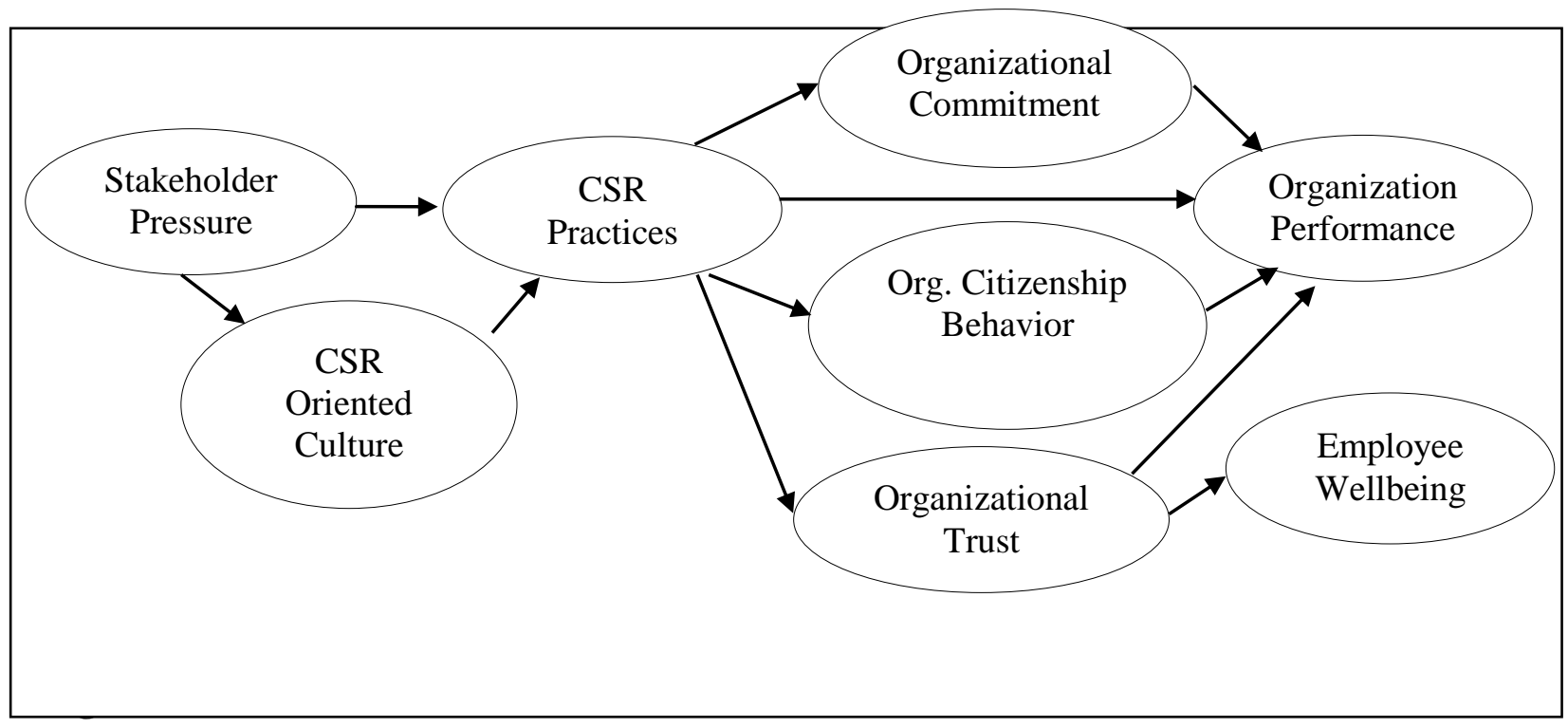

\section{Sampling Design, Data Collection and Measurement}

This quantitative study relied on survey method and used measures developed by previous researchers. Stakeholder pressure measurements were adopted from research by Sarkis et al. (2010). CSR Practices measurements were adopted from study of Fatima et al. (2014). CSR oriented culture measurements were adopted from research by $\mathrm{Yu}$ and Choi (2016). Organizational citizenship behavior, organizational commitment, trust, employee wellbeing, and performance measurements were adopted from studies of Lee and Allen (2002), Jaworski and Kohli (1993), Lee et al. (2013), Siu, Lu, and Spector (2007), and Hassan et al. (2013) respectively. To measure the responses, Likert scale with 5 points was used. Data was obtained using questionnaires form all the banks (21) in the areas of South Punjab (Multan, Rajanpur, Fazilpur, Jampur, and D.G. Khan). After several follow ups, 180 questionnaires (usable) were returned out of 200 questionnaires distributed among branch managers and operations managers (90\% response rate). Comparatively high response rate (47\%, 84/180) was obtained from HBL (19), UBL (26), Soneri Bank (17), and MCB (22). 84\% of respondents were males, 53\% were between age ranges of 31-40 years, $31 \%$ had experience between 5-8 years, and 78\% had master's degree.

\section{Analyses and Results}

\subsection{Validity and Reliability Check}

SmartPLS3.0 was used for data analyses. Due to small sample size and complexity of model this software is normally the best choice (Garson, 2016). A two steps method suggested by Chin (1998) was used for analyses. Initially, the reliability and validity of measurement of outer model was assessed. The model 
was reflective. For convergent validity, item loadings should be 0.7 and above as recommended by Carmines and Zeller (1979). Table 1 shows that loading of all items meet the standard and indicate sufficient convergent validity. Reliability was checked using Cronbach's alpha and composite reliability. Researchers such as Hair, Black, Babin, and Anderson (2010) have suggested cut off value of 0.7 for both. The statistics for these two for all constructs were also satisfactory as shown in the table 1 . Discriminant validity was measured using Fornell-Larcker Criteria (1981). The square root of AVE was compared with correlation values off-diagonal elements. The square root of AVE of constructs was higher than the correlation values in same row and column representing high discriminant validity. AVE was also higher than 0.5 indicating divergent validity. VIF values were less than 0.4 . Model fit was obtained as reflected through SRMR value, $0.086(<1)$ (Garson, 2016)

Table 1: Factor Loadings, Reliability and AVE Check

\begin{tabular}{|c|c|c|c|c|c|}
\hline Construct & Items & $\begin{array}{c}\text { Factor } \\
\text { Loadings }\end{array}$ & $\begin{array}{l}\text { Composite } \\
\text { Reliability }\end{array}$ & $\begin{array}{c}\text { Cronbach's } \\
\text { Alpha }\end{array}$ & $\begin{array}{c}\text { Average } \\
\text { Variance } \\
\text { Extracted } \\
\text { (AVE) }\end{array}$ \\
\hline \multirow{10}{*}{ CSR Practices(CSRP) } & CSR1 & 0.73 & \multirow{10}{*}{0.91} & \multirow{10}{*}{0.89} & \multirow{10}{*}{0.52} \\
\hline & CSR2 & 0.76 & & & \\
\hline & CSR3 & 0.71 & & & \\
\hline & CSR4 & 0.70 & & & \\
\hline & CSR5 & 0.70 & & & \\
\hline & CSR7 & 0.70 & & & \\
\hline & CSR9 & 0.79 & & & \\
\hline & CSR10 & 0.76 & & & \\
\hline & CSR11 & 0.74 & & & \\
\hline & CSR12 & 0.70 & & & \\
\hline \multirow{5}{*}{ Stakeholder Pressure(SP) } & SP2 & 0.70 & \multirow{5}{*}{0.84} & \multirow{5}{*}{0.77} & \multirow{5}{*}{0.52} \\
\hline & SP1 & 0.70 & & & \\
\hline & SP3 & 0.79 & & & \\
\hline & SP5 & 0.70 & & & \\
\hline & SP4 & 0.76 & & & \\
\hline \multirow{5}{*}{$\begin{array}{l}\text { CSR Oriented } \\
\text { Culture(CSROC) }\end{array}$} & CSROC2 & 0.75 & \multirow{5}{*}{0.84} & \multirow{5}{*}{0.78} & \multirow{5}{*}{0.53} \\
\hline & CSROC4 & 0.70 & & & \\
\hline & CSROC1 & 0.72 & & & \\
\hline & CSROC3 & 0.80 & & & \\
\hline & CSROC5 & 0.70 & & & \\
\hline \multirow{6}{*}{$\begin{array}{l}\text { Employee } \\
\text { Wellbeing(EW) }\end{array}$} & EWB3 & 0.70 & \multirow{6}{*}{0.88} & \multirow{6}{*}{0.85} & \multirow{6}{*}{0.57} \\
\hline & EWB2 & 0.78 & & & \\
\hline & EWB6 & 0.79 & & & \\
\hline & EWB1 & 0.74 & & & \\
\hline & EWB5 & 0.70 & & & \\
\hline & EWB7 & 0.81 & & & \\
\hline \multirow{5}{*}{$\begin{array}{l}\text { Organizational } \\
\text { Performance(OP) }\end{array}$} & OP1 & 0.70 & \multirow{5}{*}{0.88} & \multirow{5}{*}{0.84} & \multirow{5}{*}{0.57} \\
\hline & OP6 & 0.83 & & & \\
\hline & OP3 & 0.77 & & & \\
\hline & OP5 & 0.73 & & & \\
\hline & OP4 & 0.72 & & & \\
\hline
\end{tabular}




\begin{tabular}{|c|c|c|c|c|c|}
\hline & OP2 & 0.78 & & & \\
\hline \multirow{5}{*}{$\begin{array}{l}\text { Organizational } \\
\text { Commitment }(\mathrm{OC})\end{array}$} & OC4 & 0.70 & \multirow{5}{*}{0.86} & \multirow{5}{*}{0.80} & \multirow{5}{*}{0.56} \\
\hline & $\mathrm{OC} 2$ & 0.85 & & & \\
\hline & OC7 & 0.70 & & & \\
\hline & OC5 & 0.70 & & & \\
\hline & OC1 & 0.82 & & & \\
\hline \multirow{3}{*}{ Organizational Trust(OT) } & OT5 & 0.70 & \multirow{3}{*}{0.83} & \multirow{3}{*}{0.70} & \multirow{3}{*}{0.63} \\
\hline & OT2 & 0.85 & & & \\
\hline & OT1 & 0.86 & & & \\
\hline \multirow{5}{*}{$\begin{array}{l}\text { Organizational } \\
\text { Citizenship } \\
\text { Behavior(OCB) }\end{array}$} & OCB8 & 0.70 & \multirow{5}{*}{0.87} & \multirow{5}{*}{0.81} & \multirow{5}{*}{0.57} \\
\hline & OCB6 & 0.73 & & & \\
\hline & OCB5 & 0.76 & & & \\
\hline & OCB3 & 0.77 & & & \\
\hline & OCB2 & 0.82 & & & \\
\hline
\end{tabular}

4.2 Struct ural model

\section{and hypotheses testing}

Next, the proposed hypotheses were examined by running PLS Algorithm and bootstrapping (1000 samples). Figure 2 and Tables 2 present the results.

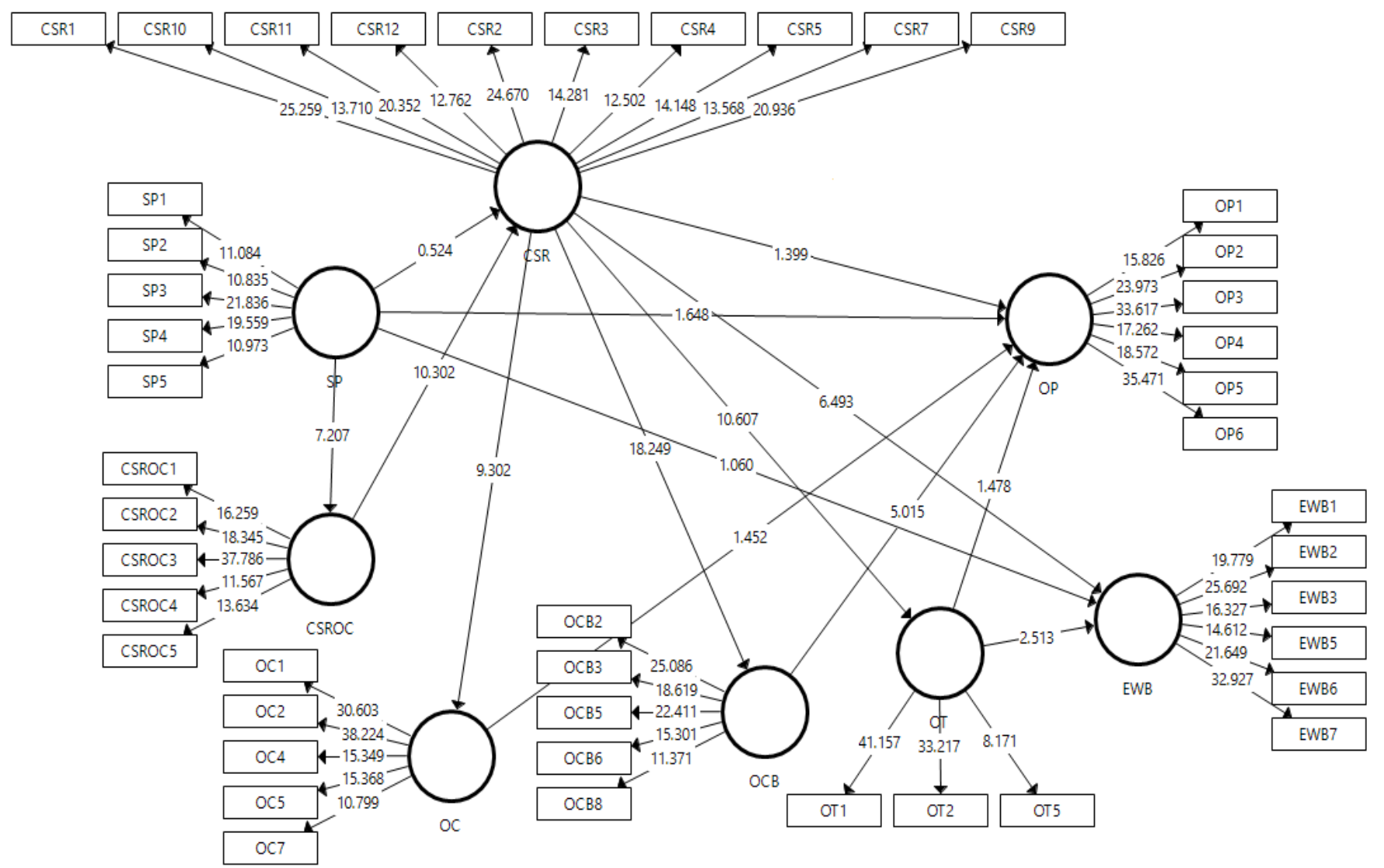

Figure 2: Structural Model

\subsection{Mediation of CSROC amongst Stakeholder Pressure and CSRP}

The table 2 results show that stakeholder pressure indirectly influence CSRP ( $\mathrm{t}$-value $=5.076$, $\mathrm{p}$ value $=0.0$ ) while it has insignificant direct influence over CSRP ( $\mathrm{t}$-value $=0.524$, $\mathrm{p}$-value $=0.600)$. These results suggest full mediation of CSROC between stakeholder pressure and CSRP (H1 is accepted). 
Table 2: Bootstrapping results

\begin{tabular}{|c|c|c|c|c|c|c|c|c|c|}
\hline \multirow[t]{2}{*}{ Effects } & \multicolumn{3}{|c|}{ Direct Effect } & \multicolumn{2}{|c|}{$\begin{array}{l}\text { Bias Corrected } \\
\text { Confidence } \\
\text { Interval }\end{array}$} & \multicolumn{2}{|c|}{ Indirect Effect } & \multicolumn{2}{|c|}{$\begin{array}{c}\text { Bias Corrected } \\
\text { Confidence } \\
\text { Interval }\end{array}$} \\
\hline & t-value & p-value & Coefficient & $2.5 \%$ & $97.5 \%$ & t-value & p-value & $2.5 \%$ & $97.5 \%$ \\
\hline $\mathrm{SP} \rightarrow \mathrm{CSRP}$ & 0.524 & 0.600 & 0.037 & -0.099 & 0.165 & 5.076 & 0.000 & 0.160 & 0.343 \\
\hline $\mathrm{CSROC} \rightarrow \mathrm{CSRP}$ & 10.302 & 0.000 & 0.579 & 0.464 & 0.684 & & & & \\
\hline $\mathrm{SP} \rightarrow \mathrm{CSROC}$ & 7.207 & 0.000 & 0.433 & 0.531 & 0.297 & & & & \\
\hline $\mathrm{CSRP} \rightarrow \mathrm{OC}$ & 9.302 & 0.000 & 0.525 & 0.411 & 0.630 & & & & \\
\hline $\mathrm{CSRP} \rightarrow \mathrm{OP}$ & 1.399 & 0.162 & 0.150 & -0.092 & 0.332 & 2.709 & 0.007 & 0.051 & 0.389 \\
\hline $\mathrm{CSRP} \rightarrow \mathrm{OCB}$ & 18.249 & 0.000 & 0.688 & 0.592 & 0.747 & & & & \\
\hline $\mathrm{OC} \rightarrow \mathrm{OP}$ & 1.452 & 0.147 & 0.142 & -0.038 & 0.327 & & & & \\
\hline $\mathrm{CSRP} \rightarrow \mathrm{OT}$ & 10.607 & 0.000 & 0.629 & 0.494 & 0.732 & & & & \\
\hline $\mathrm{OCB} \rightarrow \mathrm{OP}$ & 5.015 & 0.000 & 0.420 & 0.246 & 0.559 & & & & \\
\hline $\mathrm{OT} \rightarrow \mathrm{OP}$ & 1.478 & 0.140 & 0.148 & -0.032 & 0.362 & & & & \\
\hline $\mathbf{O T} \rightarrow \mathbf{E W}$ & 2.513 & 0.012 & 0.239 & 0.045 & 0.408 & & & & \\
\hline $\mathrm{CSRP} \rightarrow \mathrm{EW}$ & 6.493 & 0.000 & 0.483 & 0.300 & 0.602 & 2.282 & 0.023 & 0.028 & 0.245 \\
\hline $\mathbf{S P} \rightarrow \mathbf{E W}$ & 1.060 & 0.290 & 0.087 & -0.070 & 0.248 & 3.950 & 0.000 & 0.066 & 0.202 \\
\hline $\mathbf{S P} \rightarrow \mathbf{O P}$ & 1.648 & 0.100 & 0.118 & -0.047 & 0.234 & 3.687 & 0.000 & 0.083 & 0.246 \\
\hline
\end{tabular}

\subsection{Mediating impact of OC among CSRP and Performance}

Results show significant indirect impact of CSRP on performance (t-value=2.709) while direct impact of CSRP over organization performance is not significant ( $\mathrm{t}$-value $=1.399, \mathrm{p}$-value $=0.162$ ). The results further show that CSR practices' direct impact over commitment is significant, but the direct effect of commitment over organization performance is not significant ( $\mathrm{t}$-value $=1.452$ ). Because of this, $\mathrm{H} 2$ is rejected.

\subsection{Mediation of OCB among CSRP and Performance}

Table 2 shows that direct effect of CSRP on OCB is significant (t-value=18.249) and direct influence of OCB on organization performance is also significant ( $t$-value=5.015). Therefore, H3 is accepted. 


\subsection{Mediation of Organizational Trust between CSRP and Performance}

Table 2 shows that CSRP have significant direct influence over organizational trust (tvalue $=10.607)$. While organizational trust does not impact performance significantly $(\mathrm{t}$-value $=1.478, \mathrm{p}$ value $=0.140$ ). So, $\mathrm{H} 4$ is rejected.

\subsection{Mediation of Organizational Trust between CSRP and Employee Wellbeing}

Table 2 shows that CSRP's indirect and direct impacts over employee wellbeing were significant with tvalue $=2.282$, and $t$-value $=6.493$ respectively. They support organizational trust's partial mediating role among CSRP and employee wellbeing (this leads to accepting hypothesis 5).

\subsection{Test of Serial Mediators amongst Stakeholder Pressure and Organization Performance}

Table 2 shows that stakeholders pressure has significant indirect impact on organization performance ( $t$ value $=3.687$ ) while the direct effect is insignificant (t-value $=1.648$, p-value $=0.100$ ). Table 2 regarding direct effects supports mediating role of OCB only and therefore, it is concluded that stakeholder pressure impacts organization performance through (full) mediating roles played by CSR oriented culture, CSRP, and OCB. H6b is accepted.

\subsection{Test of Serial Mediators amongst Stakeholder Pressure and Wellbeing of Employees.}

Table 2 shows significant indirect influence of stakeholder pressure over employee wellbeing (tvalue $=3.950$ ), while the direct influence is insignificant ( $\mathrm{t}$-value $=1.060, \mathrm{p}$-value $=0.290$ ). Hence, the results support full mediation of organizational trust, CSRP, and CSR oriented culture amongst stakeholder pressure and employee wellbeing. This leads to accepting hypothesis 7 . Furthermore, all the significant effects have positive coefficients as shown in Table 2 which suggest positive nature of impacts. The bias corrected confidence intervals also indicated reliable results.

\section{Conclusion and Discussion}

A number of findings of this study could be supported by past studies. Firstly, mediation role CSR oriented culture amongst stakeholder pressure and CSRP is supported by many previous researches (Kalyar et al., 2013; Park et al., 2014; Yu \& Choi, 2016). Then, the findings did not reveal any mediating effect of commitment amongst CSRP and organization performance. These results are inconsistent with past researches, while, they are in line with those of Steers (1977) that commitment might not always result in performance outcomes. For further clarity, however, this hypothesis must be studied in other industries of Pakistan as well.

The results provided support for OCB's mediating effect amongst CSRP and organization performance. In this context, the results are in line with past studies' findings such as those of Hansen et al. (2011); Nisar et al. (2014); and Chun et al. (2013). Next, the study established that trust does not mediate amongst CSRP and organization performance. This conclusion supports arguments of Dirks and Ferrin (2001) that trust does not always produce positive outcomes. Further, literature shows some inconsistent findings regarding trust and organization performance link, and this link needs to be further explored, as also suggested by Zanini and Migueles (2013). Furthermore, the findings proved partial mediating impact of trust amongst CSRP and employee wellbeing, wherein nature of relationships are found to be consistent with various past studies (Bohdanowicz \& Zientara, 2009; Lee et al., 2013; Yu \& Choi, 2014a). The results also supported serial mediation hypotheses lending support to various theories mentioned in the literature. Overall, the findings support stakeholder theory, resource based view, social exchange theory, social identity theory, and organizational behavior theory concerning the relationships between variables.

\section{Practical Implications, Limitations, and Future Research}

Firm stakeholders have a concern for organization performance and employee wellbeing. The recognized importance of CSR is also due to its impact on organization performance and employee wellbeing. CSR could be better implemented if supported by organization culture. CSR develops citizenship behavior in employees that brings outcomes in the form of better organization performance and high employee 
wellbeing particularly in the banking sector. The study has certain limitations too from which first being, that the study was limited only to Pakistani banking sector. Its cross sectional design and small sample size is also a limitation. For more generalizability of results, it should be conducted in other sectors and countries. Comparative studies could be conducted across sectors or regions for better insight.

\section{References}

Agle, B.R., Mitchell, R.K., \& Sonnenfeld, J.A. (1999). Who matters to CEOS? An investigation of stakeholder attributes and salience, corporate performance, and CEO values. Academy of Management Journal, 42(5), 507-525. https://doi.org/10.2307/256973

Aguinis, H., \& Glavas, A. (2012). What we know and don't know about corporate social responsibility: A review and research agenda. Journal of Management,38(4), 932-968. https://doi.org/10.1177/0149206311436079

Ali, I., Rehman, K.U., Ali, S.I., Yousaf, J., \& Zia, M. (2010). Corporate social responsibility influences, employee commitment and organizational performance. African Journal of Business Management, 4(12), 2796-2801.

Bauman, C.W., \& Skitka, L.J. (2012). Corporate social responsibility as a source of employee satisfaction. Research in Organizational Behavior, 32, 63-86. https://doi.org/10.1016/j.riob.2012.11.002

Boadi, A. E., He, Z., Bosompem, J., Opata, C. N., \& Boadi, E. K. (2019). Employees' perception of corporate social responsibility (CSR) and its effects on internal outcomes. The Service Industries Journal, 1-23. https://doi.org/10.1080/02642069.2019.1606906

Boaventura, J.M.G., Silva, R.S.D., \& Bandeira-de-Mello, R. (2012). Corporate financial performance and corporate social performance: Methodological development and the theoretical contribution of empirical studies. Revista Contabilidade \& Finanças, 23(60), 232-245. http://dx.doi.org/10.1590/S1519-70772012000300008

Bohdanowicz, P., \& Zientara, P. (2009). Hotel companies' contribution to improving the quality of life of local communities and the well-being of their employees. Tourism and Hospitality Research, 9(2), 147-158. https://doi.org/10.1057/thr.2008.46

Carmines, E.G., \& Zeller, R.A. (1979). Reliability and validity assessment (Vol. 17). CA: Sage Publications Inc.

Chin, W.W. (1998). The partial least squares approach to structural equation modeling: Modern methods for business research. NJ: Lawrence Erlbaum Associates.

Chun, J.S., Shin, Y., Choi, J.N., \& Kim, M.S. (2013). How does corporate ethics contribute to firm financial performance? The mediating role of collective organizational commitment and organizational citizenship behavior. Journal of Management,39(4), 853-877. https://doi.org/10.1177/0149206311419662

Cropanzano, R., Byrne, Z.S., Bobocel, D.R., \& Rupp, D.E. (2001). Moral virtues, fairness heuristics, social entities, and other denizens of organizational justice. Journal of Vocational Behavior, 58(2), 164-209. https://doi.org/10.1006/jvbe.2001.1791

Cropanzano, R., \& Mitchell, M.S. (2005). Social exchange theory: An interdisciplinary review. Journal of Management, 31(6), 874-900.

Cropanzano, R., \& Rupp, D. E. (2008). Social exchange theory and organizational justice: Job performance, citizenship behaviors, multiple foci, and a historical integration of two literatures. In S. W. Gilliland, D. P. Skarlicki, \& D. D. Steiner (Eds.), Research in social issues in management: Justice, morality, and social responsibility (pp. 63-99). Greenwich CT: Information Age Publishing.

Darnall, N. (2006). Why firms mandate ISO 14001 certification. Business \& Society, 45(3), 354-381. https://doi.org/10.1177/0007650306289387

Dirks, K.T., \& Ferrin, D.L. (2001). The role of trust in organizational settings. Organization Science, 12(4), 450-467. https://doi.org/10.1287/orsc.12.4.450.10640

Donaldson, T., \& Preston, L.E. (1995). The stakeholder theory of the corporation: Concepts, evidence, and implications. Academy of Management Review, 20(1), 65-91. https://doi.org/10.2307/258887 
Du, S., Bhattacharya, C.B., \& Sen, S. (2015). Corporate social responsibility, multi-faceted job-products, and employee outcomes. Journal of Business Ethics, 131(2), 319-335. https://doi.org/10.1007/s10551-014-2286-5

El Akremi, A., Gond, J.P., Swaen, V., De Roeck, K., \& Igalens, J. (2015). How do employees perceive corporate responsibility? Development and validation of a multidimensional corporate stakeholder responsibility scale. Journal of Management. Ethics, 30(1), 73-85. https://doi.org/10.1177/0149206315569311

Fatima, M., Rahman, Z., \& Khan, I. (2014). Multi-item stakeholder based scale to measure CSR in the banking industry. International Strategic Management Review, 2(1), 9-20. https://doi.org/10.1016/j.ism.2014.06.001

Fornell, C., \& Larcker, D. F. (1981). Structural equation models with unobservable variables and measurement error: Algebra and statistics. Journal of Marketing Research, 18(3), 382-388. https://doi.org/10.2307/3150980

Freeman, R.E. (1984). Strategic management: A stakeholder approach. Boston: Pitman.

Garson, G.D. (2016). Partial least squares: Regression \& structural equation models. USA: Statistical Publishing Associates.

Gavin, J.F., \& Maynard, W.S. (1975). Perceptions of corporate social responsibility. Personnel Psychology, 28(3), 377-387. http://dx.doi.org/10.1111/j.1744-6570.1975.tb01545.x

Hair, J.F., Black, W.C., Babin, B.J., \& Anderson, R.E. (2010). Multivariate data analysis (7th ed.). NJ: Pearson Prentice Hall Inc.

Hansen, S.D., Dunford, B.B., Boss, A.D., Boss, R.W., \& Angermeier, I. (2011). Corporate social responsibility and the benefits of employee trust: A cross-disciplinary perspective. Journal of Business Ethics, 102(1), 29-45. https://doi.org/10.1007/s10551-011-0903-0

Hassan, M.U., Malik, A.A., Hasnain, A., Faiz, M.F., \& Abbas, J. (2013). Measuring employee creativity and its impact on organization innovation capability and performance in the banking sector of $\begin{array}{llll}\text { Pakistan. World Applied } \quad \text { Sciences } & \text { Journal, 24(7), }\end{array}$ https://doi.org/10.5829/idosi.wasj.2013.24.07.13253

Jaworski, B.J., \& Kohli, A.K. (1993). Market orientation: Antecedents and consequences. The Journal of Marketing, 57, 53-70. https://doi.org/10.2307/1251854

Jin, K.G., \& Drozdenko, R.G. (2010). Relationships among perceived organizational core values, corporate social responsibility, ethics, and organizational performance outcomes: An empirical study of information technology professionals. Journal of Business Ethics, 92(3), 341-359. https://doi.org/10.1007/s10551-009-0158-1

Kalyar, M.N., Rafi, N., \& Kalyar, A.N. (2013). Factors affecting corporate social responsibility: An empirical study. Systems Research and Behavioral Science, 30(4), 495-505. https://doi.org/10.1002/sres.2134

Kim, S.T., \& Lee, S.Y. (2012). Stakeholder pressure and the adoption of environmental logistics practices: Is eco-oriented culture a missing link? The International Journal of Logistics Management, 23(2), 238-258. https://doi.org/10.1108/09574091211265378

Kowalczyk, R. (2019). How do stakeholder pressure influence on CSR-Practices in Poland? The construction industry case. Journal of EU Research in Business, 2019. https://doi.org/10.5171/2019.102392.

Kramer, R.M. (1999). Trust and distrust in organizations: Emerging perspectives, enduring questions. Annual Review of Psychology, 50(1), 569-598. https://doi.org/10.1146/annurev.psych.50.1.569

Lee, K., \& Allen, N.J. (2002). Organizational citizenship behavior and workplace deviance: The role of affect and cognitions. Journal of Applied Psychology,87(1), 131-142. http://dx.doi.org/10.1037/0021-9010.87.1.131

Lee, Y.K., Kim, Y.S., Lee, K.H., \& Li, D.X. (2012). The impact of CSR on relationship quality and relationship outcomes: A perspective of service employees. International Journal of Hospitality Management, 31(3), 745-756. https://doi.org/10.1016/j.ijhm.2011.09.011

Lee, Y.K., Son, M.H., \& Lee, D.J. (2011). Do emotions play a mediating role in the relationship between 
owner leadership styles and manager customer orientation, and performance in service environment? International Journal of Hospitality Management,30(4), 942-952. https://doi.org/10.1016/j.ijhm.2011.02.002

Lee, C.K., Song, H.J., Lee, H.M., Lee, S., \& Bernhard, B.J. (2013). The impact of CSR on casino employees' organizational trust, job satisfaction, and customer orientation: An empirical examination of responsible gambling strategies. International Journal of Hospitality Management, 33, 406-415. https://doi.org/10.1016/j.ijhm.2012.10.011

Lin, C.P., Lyau, N.M., Tsai, Y.H., Chen, W.Y., \& Chiu, C.K. (2010). Modeling corporate citizenship and its relationship with organizational citizenship behaviors. Journal of Business Ethics, 95(3), 357372. https://doi.org/10.1007/s10551-010-0364-x

Lindblom, C.K. (1994, April). The implications of organizational legitimacy for corporate social performance and disclosure. Paper presented at Critical perspectives on accounting conference, New York.

Linnenluecke, M.K., \& Griffiths, A. (2010). Corporate sustainability and organizational culture. Journal of World Business, 45(4), 357-366. https://doi.org/10.1016/j.jwb.2009.08.006

Mael, F., \& Ashforth, B.E. (1992). Alumni and their alma mater: A partial test of the reformulated model of organizational identification. Journal of Organizational Behavior,13(2), 103-123. https://doi.org/10.1002/job.4030130202

Maignan, I., \& Ferrell, O.C. (2001). Antecedents and benefits of corporate citizenship: An investigation of French businesses. Journal of Business Research, 51(1), 37-51. https://doi.org/10.1016/S01482963(99)00042-9

Margolis, J.D., \& Walsh, J.P. (2001). People and profits? The search for a link between a company's social and financial performance. NJ: Lawrence Erlbaum Associates.

Nisar, Q.A., Marwa, A., Ahmad, U., \& Ahmad, S. (2014). Impact of perceived organizational support on organizational citizenship behavior: Empirical evidence from Pakistan. International Journal of Research, 1(5), 231-240.

O'Reilly, C. (1989). Corporations, culture, and commitment: Motivation and social control in organizations. California Management Review, 31(4), 9-25. https://doi.org/10.2307/41166580

Organ, D.W. (1988). Organizational citizenship behavior: The good soldier syndrome. Lexington: Books/DC Heath and Com.

Pandey, S. (2020). An empirical study on socially responsible human resource practices and wellbeing of the employees in SMEs, NCR. International Journal of Scientific Research and Engineering Development, 3(1), 1-10.

Park, B.I., Chidlow, A., \& Choi, J. (2014). Corporate social responsibility: Stakeholders influence on MNEs' activities. International Business Review, 23(5), 966-980. https://doi.org/10.1016/j.ibusrev.2014.02.008

Peterson, D.K. (2004). The relationship between perceptions of corporate citizenship and organizational commitment. Business \& Society, 43(3), 296-319. https://doi.org/10.1177/0007650304268065

Phunpon, S., \& Pumtong, S. (2012). Communicating Corporate Social Responsibility (CSR) of Pharmaceutical Companies on the Internet in Thailand. Research in Social and Administrative Pharmacy, 8(6), e48. https://doi.org/10.1016/j.sapharm.2012.08.112

Pivato, S., Misani, N., \& Tencati, A. (2008). The impact of corporate social responsibility on consumer trust: the case of organic food.Business Ethics: A European Review, 17(1), 3-12. https://doi.org/10.1111/j.1467-8608.2008.00515.x

Podsakoff, N. P., Whiting, S. W., Podsakoff, P. M., \& Blume, B. D. (2009). Individual and organizational level consequences of organizational citizenship behaviors: A meta-analysis. Journal of Applied Psychology, 94, 122-141. https://doi.org/10.1037/a0013079.

Rehman, R.U., Zhang, J., Ali, R., \& Qadeer, A. (2015). Does growing economy and better governance impede banking efficiency? A DEA analysis. Journal of Applied Business Research, 31(6), 2213. https://doi.org/10.19030/jabr.v31i6.9478

Reverte, C., Gómez-Melero, E., \& Cegarra-Navarro, J. G. (2016). The influence of corporate social responsibility practices on organizational performance: Evidence from Eco-Responsible Spanish 
firms. Journal of Cleaner $\quad$ Production, 112, 2870-2884. https://doi.org/10.1016/j.jclepro.2015.09.128

Rupp, D.E., Ganapathi, J., Aguilera, R.V., \& Williams, C.A. (2006). Employee reactions to corporate social responsibility: An organizational justice framework. Journal of Organizational Behavior, 27(4), 537-543.

Rupp, D.E., Shao, R., Thornton, M.A., \& Skarlicki, D.P. (2013). Applicants' and employees' reactions to corporate social responsibility: The moderating effects of first-party justice perceptions and moral identity. Personnel Psychology, 66(4), 895-933. https://doi.org/10.1111/peps.12030

Salavati, A., Ahmadi, F., Sheikhesmaeili, S., \& Mirzai, M. (2011). Effect of organizational socialization on organizational citizenship behavior. Interdisciplinary Journal of Contemporary Research in Business, 3, 395-410.

Sarfraz, M., Qun, W., Abdullah, M. I., \& Alvi, A. T. (2018). Employees' perception of corporate social responsibility impact on employee outcomes: Mediating role of organizational justice for small and medium enterprises (SMEs). Sustainability, 10(7), 1-19. https://doi.org/10.3390/su10072429

Sarkis, J., Gonzalez-Torre, P., \& Adenso-Diaz, B. (2010). Stakeholder pressure and the adoption of environmental practices: The mediating effect of training. Journal of Operations Management, 28(2), 163-176. https://doi.org/10.1016/j.jom.2009.10.001

Siu, O.L., Lu, C.Q., \& Spector, P.E. (2007). Employees' well-being in greater China: The direct and moderating effects of general self-efficacy. Applied psychology, 56(2), 288-301. https://doi.org/10.1111/j.1464-0597.2006.00255.x

Steers, R.M. (1977). Antecedents and outcomes of organizational commitment. Administrative Science Quarterly, 22(1), 46-56. https://doi.org/10.2307/2391745

Stone, G., Joseph, M., \& Blodgett, J. (2004). Toward the creation of an eco-oriented corporate culture: A proposed model of internal and external antecedents leading to industrial firm ecoorientation. Journal of Business \& Industrial Marketing, 19(1), 68-84. https://doi.org/10.1108/08858620410516754

Supriyanto, A., Ekowati, V., \& Maghfuroh, U. (2020). Do organizational citizenship behavior and work satisfaction mediate the relationship between spiritual leadership and employee performance? Management Science Letters, 10(5), 1107-1114. https://doi.org/10.5267/j.msl.2019.10.031

Takahashi, T., \& Nakamura, M. (2005). Bureaucratization of environmental management and corporate greening: An empirical analysis of large manufacturing firms in Japan. Corporate Social Responsibility and Environmental Management, 12(4), 210-219. https://doi.org/10.1002/csr.86

Turker, D. (2009). How corporate social responsibility influences organizational commitment. Journal of Business Ethics, 89(2), 189-204. https://doi.org/10.1007/s 10551-008-9993-8

Wang, L., Li, W., \& Qi, L. (2020). Stakeholder pressures and corporate environmental strategies: A metaanalysis. Sustainability, 12(3), 1-16. https://doi.org/10.3390/su120311721172.

Wong, Y.T., Wong, C.S., \& Ngo, H.Y. (2002). Loyalty to supervisor and trust in supervisor of workers in Chinese joint ventures: A test of two competing models. International Journal of Human Resource Management, 13(6), 883-900. https://doi.org/10.1080/09585190210134264

Yu, Y., \& Choi, Y. (2014a). Corporate social responsibility and firm performance through the mediating effect of organizational trust in Chinese firms. Chinese Management Studies, 8(4), 577-592. https://doi.org/10.1108/CMS-10-2013-0196

Yu, Y., \& Choi, Y. (2016). Stakeholder pressure and CSR adoption: The mediating role of organizational culture for Chinese companies. The Social Science Journal, 53(2), 226-235. https://doi.org/10.1016/j.soscij.2014.07.006

Zanini, M.T.F., \& Migueles, C.P. (2013). Trust as an element of informal coordination and its relationship with organizational performance. Economia, 14(2), 77-87. https://doi.org/10.1016/j.econ.2013.08.005 